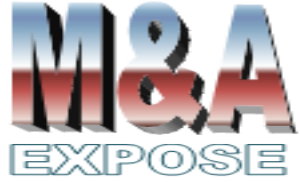

http://jurnal.usahid.ac.id/index .php/accounting
${ }^{1}$ Fakultas Ekonomi dan Bisnis Islam Universitas Islam Negeri Walisongo 1aqustby@amail.com 2ari kristin@walisongo.ac.id

\section{Pengaruh Dividend Per Share, Earning Per Share, dan Price Earning Ratio terhadap Harga Saham Syariah}

\author{
Agus Tri Budiyarno', Ari Kristin Prasetyoningrum ${ }^{1,2}$
}

\section{Abstrak}

Tujuan penelitian ini untuk menganalisis pengaruh Divident Per Share (DPS), Earning Per Share (EPS) dan Price Earning Ratio (PER) terhadap harga saham, baik secara parsial maupun simultan. Populasi adalah semua perusahaan publik yang terdaftar di Jakarta Islamic Index (JII) periode 2015-2017. Metode yang digunakan dalam penentuan sampel adalah teknik Purposive Sampling. Teknik analisis data menggunakan refresi linier berganda, yang sebelumnya telah dilakukan uji asumsi klasik. Hasil analisis data menunjukkan bahwa rasio pasar yang diproksikan dengan Divident Per Share (DPS), Earning Per Share (EPS) dan Price Earning Ratio (PER) berpengaruh positif signifikan terhadap harga saham baik secara parsial maupun simultan.

Kata Kunci : Divident Per Share, Earning Per Share, Price Earning Ratio, Harga Saham.

\section{Abstract}

The purpose of this study was to analyze the effect of Dividends Per Share (DPS), Earning Per Share (EPS) and Price Earning Ratio (PER) on stock prices, both partially and simultaneously. The population is all public companies registered in the Jakarta Islamic Index (JII) for the 2015-2017 period. The method used in determining the sample is purposive sampling technique. The data analysis technique uses multiple linear regression, which has previously passed the classical assumptions test. The results of data analysis show that market ratios that are proxied by Dividend Per Share (DPS), Earning Per Share (EPS), and Price Earning Ratio (PER) have a significant positive effect on stock prices either partially or simultaneously.

Keywords : Dividend Per Share, Earning Per Share, Price Earning Ratio, Share Price. 


\section{PENDAHULUAN}

Pasar modal merupakan sarana atau wadah untuk mempertemukan antara penjual dan pembeli instrumen keuangan dalam rangka investasi. Seiring berkembangnya sistem keuangan syariah, pasar modal berkembang menjadi pasar modal syariah. Pasar modal syariah menjadi alternatif bagi investor yang mengutamakan pilihan investasi yang mengacu pada prinsip syariah. Otoritas Jasa Keunagan (OJK) dan Bursa Efek Indonesia (BEI) terus mendorong perkembangan pasar modal syariah.

Pada tahun $2013 \mathrm{BEI}$ mencatat jumlah investor syariah sebanyak 803 investor, selanjutnya pada akhir 2015 jumlah investor syariah sudah mencapai 4.908 investor (Serfiyani, 2017). Hal ini menunjukkan bahwa minat investor terhadap pasar modal syariah meningkat cukup pesat. Perkembangan pasar modal syariah dapat diilustrasikan pada Gambar 1 berikut.

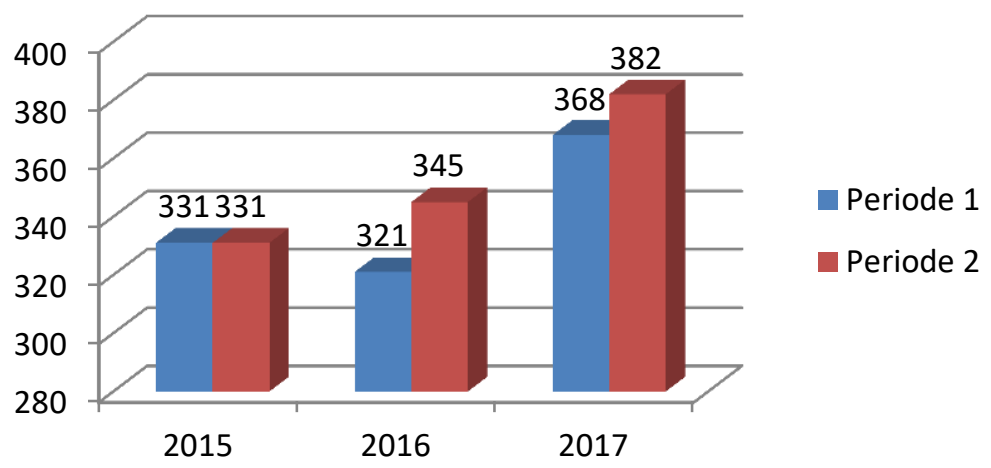

Gambar 1. Perkembangan Pasar Modal Syariah

Sumber: www.ojk.go.id

Investor melakukan investasi dengan tujuan mendapatkan keuntungan dari saham yang dibeli, berupa dividen dan capital gain. Dividen merupakan keuntungan perusahaan yang dibagikan kepada investor, sedangkan capital gain yaitu selisih harga saham saat menjual dan membeli saham tersebut. Adapun kemampuan perusahaan untuk membagikan dividen per lembar saham dapat dicermati berdasarkan rasio Dividend per Share (DPS). DPS yang tinggi mencerminkan perusahaan memiliki prospek baik dan menarik minat investor. Apabila DPS yang diterima naik, maka harga saham diharapkan akan naik (Hutami, 2012).

Earning Per Share (EPS) atau pendapatan per lembar saham adalah bentuk pemberian keuntungan yang diberikan kepada para pemegang saham dari setiap lembar saham yang dimiliki. Sulistyowati (2012) menyatakan bahwa EPS merupakan indikator utama yang digunakan investor dalam melihat daya tarik suatu saham. Apabila EPS mempunyai pertumbuhan bagus maka para investor akan tertarik untuk membeli saham tersebut sehingga akan menaikkan harga saham. Hal ini didukung oleh Safitri (2013), Damayanti et al (2014), Fauzi \& Mustanda (2016), Datu \& Maredesa (2017), dan Lilianti (2018) yang menyatakan bahwa Earning Per Share (EPS) berpengaruh positif terhadap harga saham.

Price Earning Ratio (PER) adalah perbandingan antara harga pasar saham dengan laba per lembar saham (Earning Per Share). Bagi para investor semakin tinggi Price to 
Earning Ratio (PER) maka pertumbuhan laba yang diharapkan juga akan mengalami kenaikan. Hal ini didukung oleh Sulistyowati (2012) yang menyatakan bahwa Price to Earning Ratio (PER) berpengaruh positif terhadap harga saham.

Masalah yang sering pula dihadapi oleh investor di pasar modal adalah memilih perusahaan yang tepat untuk melakukan investasi agar diperoleh investasi dengan harga yang wajar dan mencerminkan investasi potensial. Harga saham yang selalu mengalami perubahan menyebabkan investor memperhatikan faktor-faktor yang mempengaruhi harga saham. Harga saham merupakan salah satu faktor yang mempengaruhi investor dalam mengambil keputusan. Pembentukan harga saham tidak terlepas dari informasi akuntansi, salah satunya adalah kebijakan dividen. Dengan informasi kebijakan deviden, investor akan memprediksikan prospek perusahaan di masa mendatang (Lilianti, 2018).

Menurut signaling theory yang menyatakan bahwa informasi yang diumumkan oleh emiten terkait dengan informasi perusahaan nantinya dapat menjadi sinyal positif maupun negatif yang akan mempengaruhi harga saham emiten tersebut. Penelitian ini bertujuan untuk menganalisis pengaruh Dividend per Share (DPS) Earning per Share (EPS) dan Price Earning Ratio (PER) terhadap harga saham pada perusahaan yang terdaftar di Jakarta Islamic Index (JII).

\section{TINJAUAN PUSTAKA}

Saham adalah salah satu instrumen pasar modal yang paling umum diperdagangkan karena saham mampu memberikan tingkat keuntungan yang menarik. Saham adalah tanda penyertaan modal dari seseorang atau badan usaha di suatu Perseroan Terbatas (PT). Dengan dimilikinya saham, maka seseorang atau badan usaha ikut memiliki andil dalam perusahaan, sehingga berhak hadir dalam Rapat Umum Pemegang Saham (RUPS). Perusahaan yang ingin menambah modal usaha dapat menerbitkan saham dan kemudian menjual saham tersebut melalui mekanisme penawaran umum (go public) dengan bantuan perusahaan efek selaku Penjamin Emisi Efek (PEE) dan selaku Perantara Perdagangan Efek (Sefiyani, 2017). Tiga keuntungan yang diperoleh investor dengan membeli atau memiliki saham perusahaan, antara lain dividen, capital gain, dan saham bonus.

Investasi pada instrumen keuangan syariah di beberapa negara yang berpenduduk muslim terutama di Indonesia berkembang pesat. Pertumbuhan investasi syariah tersebut juga didorong oleh peningkatan permintaan investor muslim yang membutuhkan produkproduk keuangan yang tidak bertentangan dengan ajaran Islam.

Setiap investor baik jangka pendek maupun jangka panjang memiliki tujuan untuk mendapatkan keuntungan. Aalah satu yang keuntungan didapatkan dalam investasi saham adalah capital again. Capital again merupakan keuntungan dari selisih harga beli dan harga jual saham. Harga penutupan (closing price) menunjukkan harga pasar perusahaan (market value) pada akhir hari diperdagangkan. Menurut teori Miller dan Modiglini, perubahan harga saham dapat dilihat sekitar tanggal ex-dividend (setelah pembagian dividend) (Datu \& Maredesa, 2017). Investor akan lebih tertarik untuk membeli saham perusahaan yang membagikan dividend yang besar.

Pasar modal syariah secara sederhana dapat diartikan sebagai pasar modal yang menerapkan prinsip syariah Islam. Dengan demikian instrumen yang diperdagangkan di pasar modal syariah tidak boleh terkait dengan kegiatan bisnis yang diharamkan seperti 
riba, penipuan, perjudian, spekulasi, minuman keras, makanan yang mengandung babi, tempat maksiat, dan lain-lain (Serfiyani, 2017). Menurut Murtadho (2014) pengkajian pasar modal di sisi hukum Islam menjadi penting untuk diarahkan dalam mengimplementasikan misi ajaran Islam. Pasar modal tidak hanya dilihat dari halal haramnya transaksi di dalamnya, tetapi juga perlu ditelaah peluang mensyariahkan pasar modal dalam makna memanfaatkan pasar modal untuk merealisasikan misi ekonomi Islam. Pasar modal syariah di Indonesia secara resmi diluncurkan pada tanggal 14 Maret 2003 bersamaan dengan pendatanganan MOU antara Badan Pengawas Pasar Modal-Lembaga Keuangan (Bapepam-LK) dengan Dewan Syariah Nasional-Majelis Ulama Indonesia (DSN-MUI). Transaksi di pasar modal syariah tidak boleh bertentangan dengan prinsip syariah.

Jakarta Islamic Index (JII) adalah indeks saham syariah yang pertama kali diluncurkan di pasar modal pada tanggal 3 Juni 2000. Konstituen JII hanya terdiri dari 30 saham syariah paling likuid yang tercatat di BEI. Posisi Indonesia sebagai negara yang pasar keuangannya tengah berkembang, pasar modal menjadi bagian penting dalam bidang perkembangan ekonomi. Begitupun halnya pasar modal syariah Indonesia yang merupakan bagian dari pasar modal syariah internasional. Harga saham internasional dapat mempengaruhi harga saham dalam negeri maka Jakarta Islamic Index (JII) menjadi tolok ukur kinerja dalam memilih portofolio saham halal di Indonesia.

Signalling Theory menjelaskan mengapa perusahaan mempunyai dorongan untuk memberikan informasi laporan keuangan pada pihak eksternal. Teori sinyal merupakan suatu tindakan manajerial oleh manajemen perusahaan yang memberikan petunjuk kepada investor tentang prospek suatu perusahaan (Yuniep \& Meida, 2016). Informasi yang dipublikasikan perusahaan akan memberikan sinyal bagi investor, baik sinyal positif maupun sinyal negatif sesuai dengan kandungan informasi yang diterima.

Pengumuman peningkatan merupakan sinyal yang positif bagi investor karena menunjukkan kondisi likuiditas yang baik dan perusahaan mampu memenuhi kebutuhan investor berupa dividen. Namun, apabila perusahaan mengumumkan tingkat Dividend Per Share (DPS), atau Earning Per Share (EPS) dan Price Earning Ratio (PER) yang menurun, maka informasi ini diterima sebagai sinyal negatif yang menunjukkan penurunan kinerja perusahaan.

Sinyal positif maupun negatif yang diterima oleh investor akan mempengaruhi tingkat penawaran dan permintaan saham. Sinyal positif yang diterima oleh investor menyebabkan permintaan atas saham tersebut menjadi tinggi sehingga harga saham meningkat, namun jika investor menerima sinyal negatif atas suatu informasi yang diumumkan oleh emiten maka permintaan saham akan menurun sehingga harga saham juga menurun.

Bird in the Hand Theory menyatakan bahwa nilai perusahaan akan dimaksimalkan melalui penentuan rasio pembayaran dividen yang tinggi. Investor membeli saham untuk mendapatkan dividen sehingga investor yang mencari aliran laba yang stabil secara logis akan memilih perusahaan yang membayarkan dividen secara rutin daripada capital again (Hutami, 2012). Deviden adalah pembagian sisa laba bersih perusahaan kepada pemegang saham. Besarnya deviden yang diperoleh investor tergantung jumlah lembar saham yang dimilikinya (Yanti \& Suryanawa, 2015). Dividend Per Share merupakan rasio yang mengukur seberapa besar deviden yang dibagikan dibandingkan jumlah saham yang beredar.

Perusahaan yang Dividend per Share-nya lebih tinggi dibandingkan dengan perusahaan sejenis akan lebih diminati investor. Pengumuman dividen dapat dijadikan alat untuk mengirimkan isyarat kepada pasar mengenai kinerja perusahaan di masa kini dan 
masa mendatang. Setelah menerima isyarat melalui pengumuman dividen maka pasar akan bereaksi terhadap pengumuman perubahan yang dibayarkan sehingga bisa dikatakan pasar menangkap informasi tentang prospek perusahaan yang terkandung dalam pengumuman. Kenaikan dividen menjadi sinyal bagi investor bahwa manajemen perusahaan meramalkan suatu penghasilan yang baik. Selanjutnya permintaan saham perusahaan akan mengalami kenaikan sehingga terjadi kenaikan harga saham perusahaan yang bersangkutan.

Menurut Tandelilin (2010) terdapat dua komponen utama dalam analisis perusahaan yaitu Earning Per Share (EPS) dan Price Earning Ratio (PER). Earning Per Share atau laba per lembar saham dapat mengukur perolehan tiap unit investasi pada laba bersih perusahaan dalam satu periode tertentu. Setiap perubahan laba bersih maupun jumlah lembar saham biasa yang beredar dapat mengakibatkan perubahan laba per lembar saham (EPS). Adapun Earning Per Share atau pendapatan per lembar saham adalah bentuk pemberian keuntungan yang diberikan kepada para pemegang saham dan setiap lembar saham dari setiap lembar saham saham yang dimiliki (Fahmi, 2013). Laba per lembar saham menunjukkan kemampuan perusahaan untuk menghasilkan laba untuk setiap lembar sahamnya. Pengertian EPS dalam penelitian ini adalah rasio yang menunjukkan seberapa besar keuntungan yang diperoleh investor atau pemegang saham perlembar saham yang beredar selama suatu periode.

Price Earning Ratio (PER) merupakan rasio yang digunakan untuk menghitung tingkat pengembalian modal yang diinvstasikan pada suatu saham. Bagi para investor semakin tinggi Price Earning Ratio maka pertumbuhan laba yang diharapkan juga akan mengalami kenaikan. Dengan begitu Price Earning Ratio adalah perbandingan antara Market Price Per Share (Harga Pasar Per Lembar Saham) dengan Earning Per Share (Laba Per Lembar Saham).

Perusahaan dengan peluang tinggi biasanya mempunyai PER yang tinggi pula, dan ini menunjukkan bahwa pasar mengharapkan pertumbuhan laba di masa mendatang. Sebaliknya perusahaan dengan tingkat pertumbuhan yang rendah cenderung mempunyai PER yang rendah pula. Jadi semakin kecil nilai PER maka semakin murah harga saham tersebut untuk dibeli dan semakin baik pula kinerja per lembar saham dalam menghasilkan laba bagi perusahaan. Semakin baik kinerja perusahaan maka akan mempengaruhi investor untuk membeli saham tersebut.

Price Earning Ratio merupakan perbandingan antara harga pasar dengan EPS dari saham yang bersangkutan. Berdasarkan pengertian tersebut dapat diketahui bahwa bila rasio PER mengalami kenaikan maka harga saham yang ditawarkan juga akan mengalami kenaikan. PER dapat mengindikasikan harga saham yang akan datang. Rasio PER yang tinggi menunjukkan bahwa pasar mengharapkan pertumbuhan laba yang tinggi di masa mendatang. Keinginan investor menganalisis kesehatan suatu perusahaan melalui rasiorasio keuangan dikarenakan adanya keinginan investor akan hasil yang layak dari investasi suatu saham.

Divident Per Share (DPS) adalah keuntungan yang dibagikan oleh perusahaan per lembar saham. Deviden memberikan informasi pada investor terhadap perkembangan perusahaan. Hal ini didukung oleh temuan Damayanti et al (2014), Karlina dan Widanaputra (2016), Datu \& Maredesa (2017), dan Lilianti (2018) yang menyatakan Devidend Per Share (DPS) berpengaruh positif terhadap harga saham. Berdasarkan kajian pustaka tersebut, maka dapat dirumuskan hipotesis :

$\mathrm{H} 1$ : DPS berpengaruh positif terhadap harga saham perusahaan . 
Earning Per Share (EPS) adalah pemberian keuntungan yang diberikan kepada para pemegang saham dari setiap lembar saham yang dimiliki. Menurut Sulistyowati (2012) EPS merupakan indikator utama yang digunakan pemodal dalam melihat daya tarik suatu saham. Apabila EPS mempunyai pertumbuhan yang bagus maka para pemodal akan tertarik untuk membeli saham sehingga akan menaikkan harga saham. Hal ini didukung oleh temuan Safitri (2013), Damayanti et al (2014), Fauzi dan Mustanda (2016), Datu \& Maredesa (2017), dan Lilianti (2018) yang menyatakan Earning Per Share (EPS) berpengaruh positif terhadap harga saham. Berdasarkan kajian pustaka tersebut, maka dapat dirumuskan hipotesis :

H2 : EPS berpengaruh positif terhadap harga saham perusahaan.

Price Earning Ratio (PER) merupakan perbandingan antara harga pasar saham dengan laba per lembar saham (Earning Per Share). Bagi para investor, semakin tinggi Price to Earning Ratio (PER) maka pertumbuhan laba yang diharapkan juga akan mengalami kenaikan. Hal ini didukung oleh temuan Sulistyowati (2012) yang menyatakan Price to Earning Ratio (PER) berpengaruh positif terhadap harga saham. Berdasarkan kajian pustaka tersebut, maka dapat dirumuskan hipotesis :

H3 : PER berpengaruh positif terhadap harga saham perusahaan.

Sejalan dengan temuan Rusnaeni (2017) yang menunjukkan bahwa secara simultan DPS dan EPS berpengaruh positif terhadap harga saham. Berdasarkan kajian pustaka tersebut, maka dapat dirumuskan hipotesis :

H4: DPS, EPS dan PER secara simultan berpengaruh positif terhadap harga saham perusahaan.

\section{METODE PENELITIAN}

Populasi penelitian ini adalah perusahaan yang terdaftar dalam Jakarta Islamic Index. Sampel ditentukan dengan metode purposive sampling sebagai berikut:

1. Saham-saham perusahaan yang masuk dalam Jakarta Islamic Indeks (JII) yang tidak pernah delisting pada periode 2015-2017.

2. Mempublikasikan laporan keuangan tahunan audited periode 2015-2017.

3. Memiliki data sesuai variabel-variabel penelitian ini.

Setelah dilakukan pemilahan data sampel, perusahaan yang masuk dalam kriteria sampel adalah sebagaimana tercantum dalam Tabel 1.

Tabel 1. Perusahaan Sampel

\begin{tabular}{ccl}
\hline No. & Kode Saham & \multicolumn{1}{c}{ Nama Emiten } \\
\hline 1 & AKRA & PT. AKR Corporindo, Tbk \\
2 & ASII & PT. Astra Internasional, Tbk \\
3 & BSDE & PT. Bumi Serpong Damai, Tbk. \\
4 & INDF & PT. Indofood Sukses Makmur, Tbk. \\
5 & KLBF & PT. Kalbe Farma, Tbk \\
6 & LPKR & PT. Lippokarawaci, Tbk. \\
7 & LSIP & PT. London Sumatera Indonesia, Tbk \\
8 & SMGR & PT Semen Indonesia (Persero), Tbk. \\
9 & SMRA & PT. Summarecon Agung, Tbk \\
10 & TLKM & PT. Telekomunikasi Indonesia, Tbk. \\
11 & UNTR & PT. United Tractor, Tbk.
\end{tabular}

Sumber : $\underline{\text { www.idx.co.id }}$ 
Teknik pengumpulan data dilakukan dengan studi pustaka dan dokumentasi. Definisi operasional variabel penelitian adalah sebagai berikut :

1. Dividend Per Share (DPS)

Dividen Per Share (DPS) adalah total dividen yang akan dibagikan pada investor untuk setiap lembar saham. Rumus Dividen Per Share (DPS) adalah:

$$
D P S=\frac{\text { Deviden }}{\text { Lembar Saham Beredar }}
$$

2. Earning Per Share (EPS)

Earning Per Share (EPS) pendapatan per lembar saham adalah bentuk pemberian keuntungan yang diberikan kepada para pemegang saham dari setiap lembar saham dimiliki. Rumus Earning per Share (EPS) adalah:

$$
E P S=\frac{E A T}{\text { Jumlah Saham Beredar }}
$$

3. Price Earning Ratio (PER)

Price Earning Ratio (PER) merupakan rasio antara Market Price Per Share dengan

Earning Per Share. Rumus Price Earning Ratio (PER) adalah :

$P E R=\frac{\text { Market } \text { Price } \text { Per Share }}{\text { Earning Per Share }}$

Teknik analisis data dilakukan dengan regresi linier berganda. Sebelumnya dilakukan uji asumsi klasik meliputi uji normalitas, multikolinieritas, heteroskedastisitas dan uji autokorelasi.

\section{HASIL DAN PEMBAHASAN}

Analisis deskriptif digunakan untuk memberikan gambaran mengenai deskripsi variabel-variabel yang digunakan dalam penelitian yang terdiri dari Dividend per Share (DPS), Earning Per Share (EPS), Price Earning Ratio (PER), dan harga saham. Data statistik deskriptif adalah sebagaimana Tabel 2 berikut.

Tabel 2. Statistik Deskriptif

\begin{tabular}{lrrrrrr}
\hline & N & $\begin{array}{c}\text { Minimum } \\
\text { Statistic }\end{array}$ & $\begin{array}{c}\text { Maximum } \\
\text { Statistic }\end{array}$ & Mean & $\begin{array}{c}\text { Std. } \\
\text { Deviation } \\
\text { Statistic }\end{array}$ & \multicolumn{1}{c}{$\begin{array}{l}\text { Variance } \\
\text { Statistic }\end{array}$} \\
\hline DPS & 33 & 1.65 & 795.75 & 161.9861 & 198.37086 & 393950.999 \\
EPS & 33 & 36.91 & 2057.12 & 363.4558 & 423.24109 & 179133.024 \\
PER & 33 & 6.33 & 35.90 & 18.1270 & 7.34382 & 53.932 \\
Harga Saham & 33 & 488.00 & 35400 & 6012.8112 & 7137.17610 & 50939282.720 \\
$\begin{array}{l}\text { Valid N } \\
\text { (listwise) }\end{array}$ & 33 & & & & & \\
\hline
\end{tabular}

Sumber : Data diolah, 2019.

Uji normalitas bertujuan untuk menguji apakah dalam model regresi variabel terikat dan variabel bebas keduanya mempunyai distribusi normal atau tidak. Uji normalitas dengan menggunakan Kolmogorov-Smirnov. Jika nilai signifikansi lebih besar daripada 0.05, maka berdistribusi normal (Ghozali, 2006). Tabel 3 menunjukkan hasil uji normalitas bahwa Asymp. Sig. (2-tailed) memiliki nilai 0,200 pada uji variabel independen. Hasil ini lebih besar 
dari tingkat signifikansi yang ditetapkan yaitu sebesar 0,05 atau 5 persen, jadi bahwa data dalam penelitian ini terdistribusi secara normal.

Tabel 3. Uji Normalitas

\begin{tabular}{lcr}
\hline & & Unstandardized Residual \\
\hline Normal Parameters & & 33 \\
& Mean & .0000000 \\
Most Extreme Differences & Std. Deviation & 1063.09239200 \\
& Absolute & .099 \\
& Positive & .067 \\
& Negative & -.099 \\
Test Statistic & & .099 \\
Asymp. Sig. (2-tailed) & & $.200^{\mathrm{c}, \mathrm{d}}$ \\
\hline
\end{tabular}

Sumber : Data diolah, 2019.

Uji multikolinieritas bertujuan untuk menguji apakah dalam suatu model regresi ditemukan adanya korelasi antar variabel independen. Kriteria multikolinieritas dengan menggunakan VIF (Variance Inflation Factor). Jika nilai VIF tidak lebih dari 10 dan nilai tolerance tidak kurang dari 0,1 maka model regresi tersebut dapat dikatakan terbebas dari multikolinieritas (Ghozali, 2006). Berdasarkan hasil uji multikolinieritas pada Tabel 4, VIF hasil output variabel $\mathrm{X}_{1}$ (Dividend per Share), $\mathrm{X}_{2}$ (Earning Per Share), dan $\mathrm{X}_{3}$ (Price Earning Ratio) memiliki VIF tidak lebih dari 10 dan nilai tolerance tidak kurang dari 0,1 . Jadi model regresi linier berganda penelitian bebas dari multikolinieritas.

Tabel 4. Uji Multikolinieritas

\begin{tabular}{|c|c|c|c|c|c|c|c|c|}
\hline & \multirow[t]{2}{*}{ Model } & \multicolumn{2}{|c|}{$\begin{array}{l}\text { Unstandardized } \\
\text { Coefficients }\end{array}$} & \multirow{2}{*}{$\begin{array}{c}\text { Standardized } \\
\text { Coefficients } \\
\text { Beta }\end{array}$} & \multirow[t]{2}{*}{$\mathbf{t}$} & \multirow[t]{2}{*}{ Sig. } & \multicolumn{2}{|c|}{$\begin{array}{l}\text { Collinearity } \\
\text { Statistics }\end{array}$} \\
\hline & & B & Std. Error & & & & Tolerance & VIF \\
\hline \multirow[t]{4}{*}{1} & (Constant) & -2677.455 & 597.433 & & -4.482 & .000 & & \\
\hline & DPS & 6.873 & 1.966 & 191 & 3.495 & .002 & .256 & 3.905 \\
\hline & EPS & 14.072 & .938 & .834 & 14.998 & .000 & .247 & 4.047 \\
\hline & PER & 135.838 & 28.243 & .140 & 4.810 & .000 & .906 & 1.104 \\
\hline
\end{tabular}

Sumber : Data diolah, 2019.

Uji heteroskedastisitas bertujuan untuk menguji apakah dalam model regresi terjadi ketidaksamaan varians. Cara memprediksi ada tidaknya heteroskedastisitas pada suatu model dapat berdasarkan scatterplot. Jika pada scatterplot terdapat titik-titik data menyebar secara menyeluruh, tidak membentuk pola bergelombang, dan mengumpul hanya pada satu titik maka tidak terjadi heteroskedastisitas. Pada Gambar 3 terlihat bahwa pada scatterplot terdapat titik-titik data menyebar secara menyeluruh dan tidak membentuk pola bergelombang serta tidak mengumpul hanya pada satu titik. Dengan demikian maka tidak terjadi heteroskedastisitas pada model penelitian ini. 


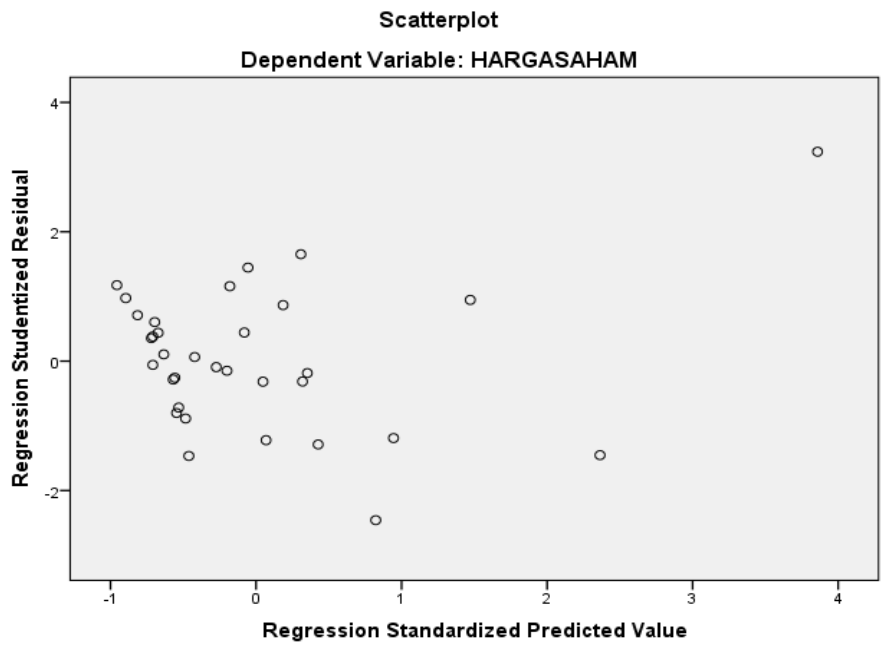

Gambar 3. Uji Heteroskedastisitas

Sumber : Data diolah, 2019.

Uji autokorelasi bertujuan menguji apakah dalam model regresi linier ada korelasi antara kesalahan pengganggu pada periode $t$ dengan kesalahan pengganggu pada periodet sebelumnya. Hal ini sering ditemukan pada data runtut waktu karena gangguan pada individu/kelompok cenderung mempengaruhi gangguan pada individu/kelompok yang sama pada periode berikutnya (Ghozali, 2006). Hasil uji autokorelasi pada Tabel 5 memperoleh nilai Durbin-Watson (DW) sebesar 1.696. Nilai DW bila dibandingkan dengan nilai tabel DW dengan jumlah observasi $(n)=33$, dengan jumlah variabel independen $k=3$, dan dengan tingkat signifikansi 0,05 atau $5 \%$ maka diperoleh nilai $d l=1.258$ dan nilai du $=1.651$. Nilai DW hitung lebih besar daripada batas atas $(d u) 1.651$ dan kurang 4-du $(4-1.651=2.349)$ atau $d u<d w<4-$ du yaitu $1.490<1.696<2.349$. Dengan demikian maka dapat disimpulkan bahwa tidak terdapat autokorelasi.

Tabel 5. Uji Autokorelasi dan Koefisien Determinasi

\begin{tabular}{lrrrrr}
\hline \multicolumn{5}{c}{ Model Summary $^{\mathbf{b}}$} \\
\hline Model & $\mathrm{R}$ & R Square & Adjusted R Square & $\begin{array}{c}\text { Std. Error of the } \\
\text { Estimate }\end{array}$ & $\begin{array}{c}\text { Durbin- } \\
\text { Watson }\end{array}$ \\
\hline 1 & $.989^{\mathrm{a}}$ & .978 & .976 & 1116.72696 & 1.696 \\
\hline a. Predictors: (Constant), PER, DPS, EPS & & & \\
b. Dependent Variable: Harga Saham \\
Sumber : Data diolah, 2019.
\end{tabular}

Tabel 7 juga menunjukkan nilai koefisien determinasi sebesar 97,6 persen yang bermakna Dividend Per Share $\left(\mathrm{X}_{1}\right)$, Earning per Share $\left(\mathrm{X}_{2}\right)$, dan Price Earning Ratio $\left(\mathrm{X}_{3}\right)$ berkontribusi menentukan variasi harga saham sebesar 97,6 persen, sedangkan 2,4 persennya ditentukan oleh variabel-variabel lain di luar model penelitian ini.

Selanjutnya goodness of fit model penelitian juga dianalisis berdasarkan Uji $\mathrm{F}$ sebagaimana hasil analisis Anova pada Tabel 6. Uji F juga dapat mengetahui pengaruh semua variabel independen yang terdapat di dalam model secara simultan terhadap variabel dependen. $F_{\text {hitung }}$ sebesar 426.033 dengan nilai signifikansi lebih kecil daripada 0,05 
menunjukkan bahwa Dividend Per Share $\left(\mathrm{X}_{1}\right)$, Earning per Share $\left(\mathrm{X}_{2}\right)$, dan Price Earning Ratio $\left(\mathrm{X}_{3}\right)$ secara simultan berpengaruh positif dan signifikan terhadap harga saham perusahaan.

\begin{tabular}{lrrrrrr}
\multicolumn{7}{c}{ Tabel 6. Uji F } \\
ANOVA $^{\mathrm{b}}$ \\
\hline \multicolumn{1}{c}{ Model } & Sum of Squares & df & Mean Square & \multicolumn{1}{c}{ F } & Sig. \\
\hline 1 Regression & 1593891753 & 3 & 531297251.0 & 426.033 & $.000^{\mathrm{b}}$ \\
Residual & 36165293 & 29 & 1247079.100 & & \\
Total & 1630057047 & 32 & & & & \\
\hline
\end{tabular}

Sumber : Data diolah, 2019.

Analisis regresi linier berganda digunakan untuk menguji pengaruh variabel variabel independen terhadap variabel dependen. Hasil analisis regresi linier berganda adalah sebagaimana Tabel 7.

Tabel 7. Analisis Regresi Linier Berganda

\begin{tabular}{|c|c|c|c|c|c|c|}
\hline & \multirow[t]{2}{*}{ Model } & \multicolumn{2}{|c|}{$\begin{array}{l}\text { Unstandardized } \\
\text { Coefficients }\end{array}$} & \multirow{2}{*}{$\begin{array}{c}\begin{array}{c}\text { Standardized } \\
\text { Coefficients }\end{array} \\
\text { Beta }\end{array}$} & \multirow[t]{2}{*}{$\mathbf{t}$} & \multirow[t]{2}{*}{ Sig. } \\
\hline & & B & Std. Error & & & \\
\hline \multirow[t]{4}{*}{1} & (Constant) & -2677.455 & 597.433 & & -4.482 & .000 \\
\hline & DPS & 6.873 & 1.966 & 191 & 3.495 & .002 \\
\hline & EPS & 14.072 & .938 & .834 & 14.998 & .000 \\
\hline & PER & 48.452 & 28.243 & .140 & 4.810 & .000 \\
\hline
\end{tabular}

Sumber : Data diolah, 2019.

Berdasarkan Tabel 7 maka diketahui bahwa persamaan regresi linier berganda penelitian ini adalah sebagai berikut :

$Y=-2677,455+6,873 X_{1}+14,072 X_{2}+48,452 X_{3}+e$

Tabel 7 tersebut juga menunjukkan hasil uji t yang mengukur signifikansi pengaruh masingmasing variabel independen :

1. Koefisien Dividend Per Share $\left(X_{1}\right)$ adalah 6,873 menunjukkan bahwa setiap kenaikan Devidend Per Share (DPS) Rp1, maka akan diikuti oleh peningkatan harga saham sebesar Rp6,873. Signifikansi koefisien $X_{1}$ sebesar 0,002 lebih kecil daripada 0,05 sehingga $X_{1}$ berpengaruh positif signifikan terhadap harga saham, jadi hipotesis 1 dapat diterima.

2. Koefisien Earning per Share $\left(X_{2}\right)$ adalah 14,072 menunjukkan bahwa setiap kenaikan Earning per Share $\left(\mathrm{X}_{2}\right) \mathrm{Rp} 1$, maka akan diikuti oleh peningkatan harga saham sebesar Rp14,072. Signifikansi koefisien $X_{2}$ sebesar 0,000 lebih kecil daripada 0,05 sehingga $X_{2}$ berpengaruh positif signifikan terhadap harga saham, jadi hipotesis 2 dapat diterima.

3. Koefisien Price Earning Ratio $\left(\mathrm{X}_{3}\right)$ adalah 48,452 menunjukkan bahwa setiap kenaikan Price Earning Ratio $\left(\mathrm{X}_{3}\right)$ 1, maka akan diikuti oleh peningkatan harga saham sebesar Rp48,452. Signifikansi koefisien $X_{3}$ sebesar 0,000 lebih kecil daripada 0,05 sehingga $X_{3}$ berpengaruh positif signifikan terhadap harga saham, jadi hipotesis 3 dapat diterima. 


\section{KESIMPULAN}

Berdasarkan hasil analisis data dan pembahasan, dapat disimpulkan bahwa Dividend Per Share $\left(\mathrm{X}_{1}\right)$, Earning per Share $\left(\mathrm{X}_{2}\right)$, dan Price Earning Ratio $\left(\mathrm{X}_{3}\right)$ baik secara parsial maupun simultan berpengaruh positif signifikan terhadap harga saham perusahaan. Bagi investor, khususnya investor syariah yang memilih berinvestasi pada saham yang terdaftar di Jakarta Islamic Index hendaknya mempertimbangkan besaran Dividend Per Share (DPS), Earning Per Share (EPS) dan Price Earning Ratio (PER) seblum mengambil keputusan membeli atau menjual saham. Penelitian selanjutnya diharapkan menambah analisis dengan rasio-rasio keuangan lainnya, serta memperpanjang rentang waktu periode penelitian.

\section{DAFTAR PUSTAKA}

Damayanti, R. P., Atmadja, A.T., \& Adipura, M.P. (2014). Pengaruh Divident Per Share dan Earning Per Share terhadap Harga Saham Industri Barang Konsumsi yang terdaftar di Bursa Efek Indonesia periode 2010-2012. E-Journal Universitas Pendidikan Ganesha.

Darmaji, T., \& Fakhrudin, H.M. (2012). Pasar Modal di Indonesia Pendekatan Tanya Jawab. Jakarta : Salemba Empat.

Datu, C. V., \& Maredesa, D. (2017). Pengaruh Dividend Per Share dan Earning Per Share terhadap Harga Saham Pada Perusahaaan Go Public di Bursa Efek Indonesia. Jurnal Riset Akutansi Going Concern, 12.

Eka, Y., Nova, N.P., \& Suryana, I.K. (2013). Pengaruh Earning Per Share terhadap Harga Saham dengan Devidend Per Share Sebagai Variabel Moderasi. E-Jurnal Akutansi Universitas Udayana.

Fahmi, I. (2013). Pengantar Pasar Modal Panduan Bagi Para Akademis dan Praktisi Bisnis dalam Memahami Pasar Modal Indonesia. Bandung : Alfabeta.

Fatwa Dewan Syariah Nasional Majlis Ulama Indonesia Nomor 40/DSN-MUI/X/2003 tentang Pasar Modal dan Pedoman Umum Penerapan Prinsip Syariah di Bidang Pasar Modal.

Ghozali, Imam. (2006). Aplikasi Analisis Multivariate dengan Program SPSS. Semarang: Badan Penerbit Universitas Diponegoro.

Hartono, J. (2000). Teori Portofolio dan Analisis Investasi. Yogyakarta : BPFE UGM.

Horne, J. C. V, \& Wachowicz, Jr, J.M. (2014). Prinsip - Prinsip Manajemen Keuangan. Edisi 13 Buku 1, Jakarta : Salemba Empat.

Hutami, R.P. (2012). Pengaruh Dividend Per Share, Return On Equity, dan Net Profit Margin terhadap Harga Saham Perusahaan Industri Manufaktur yang Tercatat di Bursa Efek Indonesia Periode 2006-2010. Jurnal Nominal, 1(1).

Lilianti, E. (2018). Pengaruh Dividend Per Share (DPS) dan Earning Per Share (EPS), Terhadap Harga Saham pada Perusahaan Sub Sektor Farmasi di Bursa Efek Indonesia (BEI). 3(1).

Murtadho, A. (2014). Pensyariahkan Pasar Modal dalam Perspektif Maqosid Al-Syariah Fi Al-lqtishad. Jurnal Economica. 10.(2). 
Yuniep M., \& Meida, D. (2016). Pengaruh Earning Per Share dan Price Earning Ratio terhadap Debt To Equity Ratio dan Harga Saham Pada Perusahaan Sektor Makanan dan Minuman di Bursa Efek Indonesia. 10(1).

Serfiyani, C.Y. (2017). Capital Market Top Secret - Rumusan Sukses Bisnis Pasar Modal Indonesia. Yogyakarta : Penerbit Andi.

Sulistyowati, Y. (2012). Pengaruh Earning Per Share, Price to Earning Ratio, dan Devidend Payout Ratio terhadap Harga Saham. Jurnal Modernisasi, 8(3).

Tandelilin, E. (2010). Portofolio dan Investasi :Teori dan Aplikasi. Yogyakarta : Kanisius. 